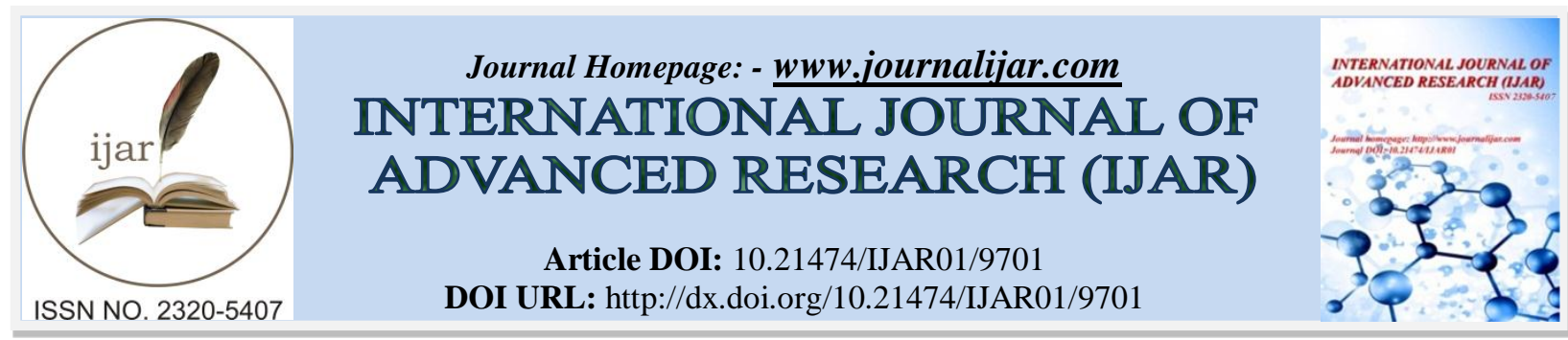

RESEARCH ARTICLE

\title{
VOTER EDUCATION AND PARTICIPATION IN ELECTIONS IN CROSS RIVER STATE.
}

\section{Patrick O. Odey ${ }^{1}$, Okputu Simon Ogana ${ }^{2}$ and Ntui Daniel Okorn ${ }^{3}$.}

1. Department of History and International Studies University of Calabar, Calabar.

2. General Studies Unit, Cross River University of Technology, Okuku Campus.

3. INEC, Akwa Ibom State, Nigeria.

\section{Manuscript Info}

Manuscript History

Received: 08 July 2019

Final Accepted: 10 August 2019

Published: September 2019

Key words:-

Voters, Education, Participation, Elections.

\begin{abstract}
The critical role of education and participation of electorates in elections is crucial to the survival and sustenance of democracy in the Cross River State. This paper examines the relationship between Voter education and participation in elections in the state. The paper establishes that given the level of education of the electorates, there is compelling need for providing awareness and enlightenment to the citizens on the importance and necessity of exercising their franchise. On this basis, the paper highlights the correlation between education and participation of eligible voters in the electoral processes. The paper adopts the neo-liberalist theory as the framework of analysis and uses qualitative descriptive data collection technique and analysis. The qualitative descriptive method is based on secondary sources. On the basis of findings, the lukewarm attitude towards Voter education accounts for the poor turnout and participation of voters in elections. More so, the win-by-all-cost syndrome has dampened the spirit of the electorates in casting their votes among other reasons. The paper therefore recommends effective education of voters to enhance their participation in elections. Thus, unless and until the education of voters is given the seriousness of attention it deserves, the enhancement of meaning electioneering activities and the realization of free, fair and credible elections in Cross River State remains a mirage.
\end{abstract}

Copy Right, IJAR, 2019,. All rights reserved.

\section{Introduction:-}

The voter is a critical stakeholder in every democratic setting, because democracy is a people-centred system of government. This is in tandem with the assertion of the German pioneer democratically elected president, Friedrich Ebert that: "Without democrats, there can be no democracy" (INEC \& FES, 2011, p. 6). The beauty of democracy is evident when this critical stakeholder participates within the ambits of extant laws governing the electoral process. This participation is to a long extent determined by the quality of education regarding the electoral process from the electoral umpire, the political parties, and civil society groups. Education makes an individual a functional member of his/her society. In the context of this study, there exist a nexus between voter education and participation in the electoral process in a democracy. The Nigerian experience in voter education has seen state-owned agencies like the National Orientation Agency, Election Management Bodies (EMBs), education institutions; faith-based and traditional institutions, Civic Society Organizations, political parties utilizing the print, non-print, and social media to educate eligible voters during election periods.

Corresponding Author:-Patrick O. Odey.

Address:-Department of History and International Studies University of Calabar, Calabar. 
What is voter education? Voter education (awareness) is an enlightenment exercise preceding electoral event. It is aimed at providing basic information enabling qualified citizens to vote, including date, time, and place of voting; the type of election; identification necessary to establish eligibility; registration requirements; and mechanis ms for voting (Yerevan 2006). Civic education, voter education and voter information are related. However, there exist some distinctions. Civic education is a continuous process taught in school, by civic society groups, electoral umpire that emphasises both citizens' awareness and participation in all aspects of democratic society; while voter information and voter education are part of civic education. Thus, civil education is the long-term process of strengthening democracy, not only focusing on the electoral process and voting (Peters-Berries, 2005, p.37). Voter education addresses Voter motivation and preparedness to participate fully in elections (ACE). The term voter education is generally used to describe the dissemination of information, materials and programme designed to inform electorates about the specifics and mechanics of the voting process for a particular election. Voter education in this regard, involves providing information on who is eligible to vote, where and how to register, how the electorate can check the voters list to ensure they have been duly registered, election date and other information about the electoral process by the EMB (in the case of Nigeria, INEC), National Orientation Agency(NOA), political parties among others.

The voter is a central actor in every election. Voter participation in the electoral process is integral to the successful running of any democracy and the very basis of wholesome democracy. Thus, it becomes an integral part of election management. In India and across the world, the imperative of enhanced Voter participation in Elections is no more a matter of debate, but a serious assignment. In recent decades, however, the world has seen a decline in Voter participation in elections, which would inevitably point to a democracy deficit.

Cross River State earned her name from the Cross River, a major geographical feature that originates from the Nigeria-Cameroon areas in the Middle Cross River region and flows to the lower Cross River region. It is located on latitude 4'30' and 7'00'N and longitude 7'50' and 9'28'E. To the north, it is bounded by Benue State, south by the Atlantic Ocean, east by the Republic of Cameroon, and west by Abia, Akwa Ibom, and Ebonyi States. The state was christened Cross River in 1976 comprising of what is now Akwa Ibom and Cross River States by the Murtala Muhammed's military regime. Prior to this time, the area so referred had existed as a "minority" area under the Igbo-dominated Eastern Region before the Gowon's regime ended the regionalization of the country with the creation of 12 States on the eve of the Civil War in 1967, as South-Eastern State. The current composition of the State was realized with the excision of Akwa Ibom State in 1987. The State has 18 local government areas, a state capital in Calabar and is geo-politically located in the South-South zone of Nigeria, a zone that hosts the major revenue earner (crude oil) in the country. The state has three(3) senatorial districts- North, Central, and south; eight(8) federal constituencies, and twenty-five(25) state constituencies.

Calabar, the Cross River State was not only capital of Nigeria but was among the two cities selected by the colonial administration when the elective principles became operational in the 1920s. The other city chosen during the era of municipal political participation was Lagos. Since 1967, ten(10) military governors had ruled the state beginning from Brigadier Udoakaha J. Esuene and ending with Navy Captain Christopher Osondu. The state has been governed by five(5) civilian governors and the sixth on the saddle. The first was Clement Isong and the incumbent, Ben Ayade.

\section{Theoretical Framework}

The paper adopts neo-liberalist theory as its theoretical framework. It holds that human nature is basically good and that innate goodness makes societal progress possible. Evil or unacceptable human behavior is the product of inadequate or corrupt social institutions and lack of understandings among leaders (Mingst, 1999; Kaarbo and Ray, 2011). Liberals believe that through collective action, the state can eliminate the possibility of conflict (Mingst, 1999). Neo-liberal theory is a product of Enlightenment Optimism of the $19^{\text {th }}$ century political and economic liberalism and the $20^{\text {th }}$ century Wilsonian Idealism. The contribution of this theory rests on the idea that individuals are rational human beings, able to understand the universally applicable laws governing both nature and human society. Understanding such laws means that people have the capacity to improve their conditions by creating a just society. If a just society is not attained, then the fault rests with inadequate institutions, the results of a corrupt environment. Therefore, to overcome defects in the society, education is imperative as it prepares one for civil life. It is pertinent that eligible voters be educated properly to participate in the election of their representatives in government. 
A government that educates its citizens politically expresses the wish to govern with the people and for the people (Mhaiki, 1981). Invariably, a government that gives political education to the people wishes to get the support of the people. Put simply, Voter education and participation is a necessary weapon for democracy to thrive since democracy demands that the process of decision-making is a shared responsibility. For the citizens cannot effectively exercise democratic decision-making without being politically conscious.

Liberalism advocates a preference for democracy and freedom over aristocracy because it sees man as capable of satisfying his natural needs and wants in a rational way. Such needs and wants could be achieved most effectively by the pursuit of freedom and autonomy through making right decisions. According to Liberal thought, individual freedom and autonomy can best be realized in a democratic state. Thus, the best society is that which permits the maximum of individual freedom, human rights and equality in the exercise of corporate social responsibility.

\section{Importance of Voter Education}

Voter education in a democratic dispensation is pivotal to sustainable democracy, guaranteeing political accountability and stability, towards national development. Both the government and the governed would interact not just on the basis of gaining votes every election year but sustained political interaction on the electoral process to have voters equipped with the pre-requisite knowledge to achieve a credible electoral process. Section 2 (a) and (b) of the Electoral Act 2010(as amended) provided that the INEC should conduct voter and civic education and promote the knowledge of sound democratic elections processes. Voter education for effective participation of the electorate in the electoral process has been pivotal to INEC. It is one of the tripartite departments of the Electoral Institute located in Ibadan, Nsukka, Oghara, Nassarawa and Zaria.

In order to provide effective strategies for voter education, INEC set up the National Inter-agency Advisory Committee on Voter Education (NICVEP) for the 2015 general elections. Commenting on the importance of enlightened voters, the then Chairman of INEC, Attahiru Jega noted that:

Although, democracy has come to stay in Nigeria with 15 uninterrupted years, the majority of Nigerians seem apathetic to elections, going by statistics available from voter turnout at election over this period. One of the major reasons for the apathy and resultant low participation in elections can be attributed to low level of awareness on electoral matters by citizens. To this end, the electorate is expected to be mobilized for full and informed participation. (NAN, 2014)

Voter apathy, electoral fraud and violence, bad governance leading to loss of confidence in the gladiatorial elite in government have been responsible for low turnout during elections and the necessitating aggressive voter education. At the national level, the NICVEP has the INEC Information and Publicity Committee heading and at the states and local government levels, the INEC Resident Electoral Commissioners (RECs) and Electoral Officers (EOs) respectively $(N A N, 2014)$.

Following the lead of INEC on the NICVEP, the then chairman of the Cross River State committee on voter education, Mike Igini, outlined the 7 point terms of reference to the 18-member committee:

1. Advise on effective strategies for public enlightenment and Voter education, identify various organizations and agencies capable of undertaking voter education activities and recommend appropriate support for them;

2. Prepare for the distribution of Permanent Voter Card and commencement of Continuous Voter Registration;

3. identify those organization and agencies that can contribute resources to voter education and develop agreed strategies for engaging with them;

4. Assist in the provision of materials for Voter Education as well as their distribution and dissemination to target groups;

5. encourage the pooling of resources and proper utilization of all available channels and platforms for voter education;

6. undertake periodic review of Voter education activities in the state. (Okon-Effiong, 2014)

Granted that Voter education is needed for increased electoral participation in a democracy like Nigeria's and Cross River State's in particular, the various political parties, civil society groups, INEC and the Cross River State Independent Electoral Commission (CROSIEC), and the state Ministry of Information, traditional and faith-based institutions have adopted aggressive socialization and enlightenment strategies through inter-personal contacts, legendary media, and the social media. For instance, preparatory to the 2015 polls, faith-based groups 
conscientiously mobilized adherents on the necessity of credible, free and fair elections due to the dangerous predictions made by analysts. The Director, JDPC Calabar Archdiocese, Rev. Fr. Emmanuel Bekomson reiterated the importance of the polls to Nigeria and the world following the collective participation of Nigerians of voting age in ensuring a violent-free election. The Muslim representative in Cross River State, Mallam Sha'aba Abdulahi in the inter-faith violence-free election conference in Calabar, joined in the call for peace in this critical period of the nation's history and advised politicians to stop ethnic or religious sentiments in their campaigns because of its divisive consequence.

Both the electorate and the election officers are provided with learning opportunities to understand the whole electoral process. This mutual benefit of voter education is based on the fact that the electoral officers mandated by the EMB (INEC) condition the perception of the electorates in line with the electoral process with a sole aim of achieving a credible, free and fair electoral process.

\section{Voter Education and Election Participation in Cross River State}

The political antecedence of the state leaves no one in doubt about political participation especially during civilian rule. The protracted period of military rule that militarized the political space limited political participation. The fanfare that heralded the inauguration of the fourth republic evaporated with the bad governance leading to failed expectations and electoral apathy on the part of the governed. According to Christian Peter-Berries (2005) the indicators on the impact of Voter education include: "election participation rate; number of null and void votes; incidents of election-related violence; and choice of candidates" (p.37).

The result released by INEC in the 2015 presidential election in which the PDP won in Cross River State had the following statistics:

1. Total valid votes: 450,514

2. Rejected votes: 15,392

3. Total votes cast: 465,906

4. L.G.As: 18

5. Political Parties: 14

6. Registered voters: $1,144,288$

7. Accredited voters: 500,577(www.360nobs.com)

The figure revealed that over half of the registered voters did not vote and the number of invalid votes cast call for concern. The reason for low turnout may not be unconnected to voter apathy resulting from previous charade in the electoral process. A situation where all the elective positions are occupied by the PDP, a reflection of the power of incumbency, robbed the electorates the spark of democratic governance as evident in other climes.

The spate of voter apathy has generated global concern. Granted that voters are indispensable stakeholders for the survival of democracy, their abysmal participation in elections questions the credibility and sustenance of the electoral process of any democratic or democratizing nation. However, there is no yardstick for Voter participation but when the turnout is far lesser than the eligible voting capacity of a defined polity, low turnout is obvious.

Some factors may be responsible for voter low turnout.

Electoral malpractice will continue unabated to a point of sophistication given the innovations in science and technology. Arthur Nwankwo (1987) doubted the possibility of Voter education curbing electoral malfeasance in these words:

And to suggest that such malpractices might be minimized or remedied in the future if the Nigerian electorate were made to acquire a higher level of political awareness through formal education, is to ignore the fact that the character of political consciousness is as important as the content of the education received, whether formal or informal. The protagonists of this view should rather remember that the problem is not so much that of lack of formal education as it is not so much that of lack of formal education as it is due to the dearth of national consciousness. (104)

Dearth of formal education as rightly queried is not responsible for the electoral recklessness of the politicians and their foot-soldiers. Even when it is narrowed down to voter education, the integrity of the educator/facilitator should be considered as well. This is why some scholars have argued that voter education does not necessarily translate to improved participation in elections rather promotes apathy. 
Election participation in Cross River State had dwindled since 2003 due largely to the one-party posture of the state, the impunity and ill-representation of the masses. However, the ethno-religious factor that played out in the 2011 general election involving a Southern Christian "minority" Goodluck Jonathan of the PDP and the Northern Muslim Fulani Muhammedu Buhari of the CPC increased participation. At the state level, the gladiatorial schemes of the politicians especially of the PDP utterly disregarded the electorates on whom sovereignty rest to perpetrate a one party state. The absent of credible opposition(s) and the zero-sum disposition of the politicians in the fourth republic (since 2003) has made the people disinterested in elections because their votes hardly count.

The arbitrariness and ill-timing of Voter education in the state impede participation during elections. The attention committed to the education of the voters by the stakeholders earlier mentioned especially INEC, is inadequate. There is the absence of sustained enlightenment until the eve of elections. It could be surmised that this is deliberate to disenfranchise the electorates as elections are conducted and won long before they are conducted. A situation room report on the 2015 elections observed the failure of INEC to adhere to the timelines in its Strategic Plan 20122016 that listed the inauguration and take off of the NICVEP, pivotal to improving voter education(Nigeria Civil Society Situation Room, 2015, 93-94).

It is worthy to stress that awareness of the electoral process does not translate to greater participation in the process especially elections. The Indian experience is illuminating:

There is lot of gap between what the voters 'should know' and what they 'actually know' in important areas like registration, EPIC/ identity proofs, Polling Station location, use of EVMs, timings of the poll, do's \& don'ts with regard to Model Code of Conduct, use of money/ muscle power or inducements by some candidates or their associates to influence vulnerable sections of electorate. These knowledge needs have also to be addressed by election managers with a sense of urgency.(Election Commission of India, 2014, p. 1)

Most times the facilitators of voter education are protégés of the incumbent and as such are selective of the teaching experiences they transfer to the electorates. If this is not the case in Cross River State, why would the electorates be disinterested in elections? Why is there no credible opposition in the face of the failed expectations? It has been observed that while the statistics of registered voters continue to soar because of increase in population and the stringent conditions attached to registration and possession of valid Permanent Voter Card (PVC) turnout has been dwindling every election year. The fall in the turnout of voters has been exploited by the politicians to "creatively redistribute unused votes to their advantage".(Centre for Democracy and Development, 2014, p.2). Rather than engage the electorates, the Director Centre for Democracy and Development, Idaat Hassan upheld that Nigerian post-independence politicians have reduced elections to "mere contest between individuals, religious or ethnic groups struggling for access and/or control over state resources"(Abbas, 2014). The electorates are robbed their kingly position by the godfathers. This rape has led to the imposition of unpopular candidates, rigging, and insensitivity of occupiers of supposedly elective positions.

There are challenges to Voter education in Cross River State- the dearth of funds which is a national embarrassment from INEC to CROSIEC at the state level. This has fastened the electoral process to the apron strings of the gladiatorial political class in Cross River State, justifying the cliché "one who pays the piper dictates the tune." Electoral officers are compelled to compromise because of paucity of funds to provide the needed logistics for a credible, free, and fair electoral process. Closely related is the inadequate capacity in terms of personnel to drive the voter education programme. The limited scope of the curriculum of voter education is a challenge that could explain why positive results are yet to be fully realized. The curriculum according to CDD: "are not context or issue specific, and often dwell on teaching electorates how to vote correctly; what and what not to do on Election Day, and in certain instances before Election Day."(2014, p. 8)

\section{Conclusion:-}

The voter is pivotal in every democratic polity and an enlightened voter improves participation in the electoral process. A bottom-top strategy should be adopted to increase and sustain voter education because of the socioeconomic challenges- poverty, hunger, and disease in the rural areas that have made inhabitants vulnerable to the fraudulent schemes of the gladiatorial political elite who only use them to access power by all means possible.

The youths and women are mostly victims of this political exploitation because they provide the population necessary for electoral victory and the youths constituting the docile army for electoral violence. Therefore, when 
the rural dwellers like their urban counterparts become sufficiently enlightened about the electoral process and the responsibilities of both the government and the governed, electoral participation will be improved and violence will be mitigated as change of government can only be realized through peaceful casting of ballots. Voter education should be intensified at the school level as the quality of the electorates can be enhanced with generations of enlightened voters from the schools are produced every year. There is need to improve on social security for citizens majority of whom are rural dwellers. The rate of poverty, illiteracy, hunger, and diseases in the hinterlands, make inhabitants vulnerable to electoral manipulations and rape of the electorates' mandate.

The recommendation of the Justice Muhammadu Uwias' Electoral Reforms on the use of state media to educate the electorates on the electoral process without any political encumbrances and the involvement of both religious and traditional institutions will enhance voters' participation in elections. Voters should be educated by facilitators who are patriots and pro-democratic, if not the quality of education will be inimical to democratic sustainability in Cross River State in particular and Nigeria in general.

The curriculum content of voter education should be elaborate enough to cover contending issues like ethnoreligious factor and its divisive effects in elections and the country, voters should be taught the essence of issuebased campaigns. Since Cross River State has both rural and urban communities, the voters in these areas should be integrated with their geographical and socio-economic peculiarities taken into consideration. Above all, voter education should be a continuous process and not ad hoc. The government, donor agencies should provide adequate funds for voter education. Political parties should pursue issue-based campaigns and mobilize their supporters on the gains of sustaining democracy in a peaceful polity. There should be a synergy between INEC/CROSIEC and relevant civil society groups to intensify voter education. The involvement of INEC in the 2016 Calabar Carnival with a Band to enlighten voters on the need to preserve their PVCs for future elections should be a sustained effort and a pace for other electoral stakeholders should follow.

\section{Bibliography:-}

1. Abbas, Jimoh. "2015: CDD call for citizens' social re-orientation” DAILY TRUST, November $18,2014$. www.dailytrust.com.ng. Accessed November 28, 2016.

2. ACE, https://aceproject.org/ace-en. Accessed June 23, 2016.

3. Centre for Democracy and Development (2014). "Who is the king maker in Nigeria: The voter or the Godfather? Briefing note on the voter education and the 2015 elections in Nigeria"www.academia.edu. Accessed October 12, 2016.

4. Electoral Act 2010 (as amended).

5. Election Commission of India (2014). Systematic Voter education and election participation(SVEEP).Compendium of instructions.

6. Independent National Electoral Commission and Friedrich-Ebert-Stiftung (2011). Voter apathyAnd the 2011elctions in Nigeria: A research report. Lagos: Muhamsaid Commercial Press.

7. "INEC inaugurates advisory committee on voter education, publicity," NAN, May 16, 2014.Posted by Naija247news. Naija247news.com. Accessed November 27, 2016.

8. Nsa, Gill. "Calabar Stakeholders sue for Violence-free Polls" DAILY INDEPENDENT February 16, 2015 http://dailyindependentnig.com (Accessed March 14, 2015)

9. Nigeria Civil Society Situation Room (2015). Report on Nigeria's 2015 general elections 28March \& 11 April 2015.Abuja: Policy and Legal Advocacy Centre (PLAC).

10. "Nigeria 2015Presidential Elections: Cross River State- PDP wins \#NigeriaDecides"March $31,2015$. www.360nobs.com. Accessed November 27, 2016.

11. Nwankwo, Arthur (1987). The Military option to Democracy: Class, Power and Violence inNigerian Politics. Enugu: Fourth Dimension Publishing Co. Ltd.

12. Okon-Effiong, Dian (2014). "INEC inaugurates Inter-agency Advisory Committee on Voter Education, Publicity in Cross River" www.africanewscircle.com. Accessed November 27,2016.

13. Peters-Berries, Christian (2005). "Voter Education in Malawi" Conflict Trends Issue 1, 37-41.www.ku.ac.ke. Accessed June 21, 2016.

14. Yerevan, Armenia (2006), "The Concepts of Civil Education, Electoral Education and Voter Awareness" International IDEA, 26 June- 4 July, 2006 www.idea.int/europe_cis. Accessed June 23, 2016. 